\title{
Quality of different tropical fruit cultivars produced in the Lower Basin of the São Francisco Valley ${ }^{1}$
}

\author{
Qualidade de cultivares de diferentes frutas tropicais produzidas no Submédio do \\ Vale do São Francisco
}

\author{
Patrício Ferreira Batista ${ }^{2 *}$, Maria Auxiliadora Coêlho de Lima ${ }^{3}$, Danielly Cristina Gomes da Trindade ${ }^{3}$ e Ricardo \\ Elesbão Alves ${ }^{4}$
}

\begin{abstract}
The present study evaluated the physical, physico-chemical and chemical characteristics of fruit from commercial cultivars of the mango, acerola, guava, atemoya and custard apple, produced in the Lower Basin of the São Francisco Valley. Fruit harvested in commercial areas of the region were evaluated for weight, length, diameter, colouration of the peel and pulp, firmness, $\mathrm{pH}$, titratable acidity (TA), soluble solids (SS), SS to TA ratio, and levels of total soluble sugars, reducing sugars, starch and pectic substances. The data were subjected to descriptive statistical analysis. Fruits from cultivars of the guava (Paluma, Rica and Pedro Sato), the custard apple and atemoya display a high level of pectic substances, a characteristic which favours industrial use. In the mango, a high level of pectic substances was noted in fruit of the cultivars Kent, Espada, Tommy Atkins and Van Dyke. Fruits of the acerola cultivar Costa Rica show high SS content and a low AT, favouring consumption in natura.
\end{abstract}

Key words: Sensory characteristics. Postharvest. Tropical fruits.

RESUMO - O presente estudo avaliou as características físicas, físico-químicas e químicas dos frutos de cultivares comerciais de mangueira, aceroleira, goiabeira, atemoieira e pinheira produzidas no Submédio do Vale do São Francisco. Frutos colhidos em áreas comerciais da região foram avaliados quanto à massa, comprimento, diâmetro, coloração da casca e polpa, firmeza, pH, acidez titulável (AT), teor de sólidos solúveis (SS), relação SS/AT, teores de açúcares solúveis totais, açúcares redutores, amido e substâncias pécticas. Os dados foram submetidos à análise estatística descritiva. Os frutos das cultivares de goiabeira (Paluma, Rica e Pedro Sato), da pinheira e da atemoieira apresentam alto teor de substâncias pécticas, característica que favorece o aproveitamento industrial. Em mangueira, alto teor de substâncias pécticas foi observado nos frutos das cultivares Kent, Espada, Tommy Atkins e Van Dyke. Os frutos da cultivar de aceroleira Costa Rica apresentam alto teor de SS e baixa AT, favorecendo o consumo in natura.

Palavras-chave: Características sensoriais. Pós-Colheita. Frutas tropicais.

\footnotetext{
*Autor para correspondência

${ }^{1}$ Recebido para publicação em 27/11/2013; aprovado em 07/11/2014

Parte da Dissertação de Mestrado do primeiro autor, apresentado ao Programa de Pós-Graduação em Fitotecnia da Universidade Federal Rural do Semiárido

${ }^{2}$ Programa de Pós-Graduação em Fitotecnia, Universidade Federal Rural do Semiárido, Av. Francisco Mota, nº 572, Bairro Costa e Silva, Mossoró-RN, Brazil, 59.625-900, patriciosfb@gmail.com

${ }^{3}$ Embrapa Semiárido, BR 428, Km 152, Zona Rural, Caixa Postal 23, Petrolina-PE, Brazil, 56.302-970, auxiliadora.lima@embrapa.br; danielly. trindade@embrapa.br

${ }^{4}$ Embrapa Agroindústria Tropical, Rua Dra. Sara Mesquita, No 2270, Bairro Planalto do Pici, Fortaleza-CE, Brazil, 60.511-110, ricardo.alves@ embrapa.br
} 


\section{INTRODUCTION}

Its continental size and the diversity of fruit available for consumption make Brazil a promising field for the expansion of fruit production. Whether for the local or regional market, or for export, the country is increasing its productive areas each year. Currently, Brazil is the third largest fruit producer after India and China. In 2012, the country exported 693,020,403 tonnes, achieving a turnover of US $\$ 618,821,149.00$ (ANUÁRIO BRASILEIRO DA FRUTICULTURA, 2013; INSTITUTO BRASILEIRO DE FRUTAS, 2012).

The fruit production hub of Petrolina in Pernambuco (PE) and Juazeiro in Bahia (BA), stands out as the major fruit producer in Latin America. According to data from the Development Company of the São Francisco and Parnaíba Valleys, the hub has about 120,000 hectares devoted to agriculture. Fruit production predominates, especially mango, grapes, banana, coconut, acerola, guava, custard apple and atemoya. About one million tonnes of fruit are produced annually in the region, $70 \%$ destined for the domestic market, more specifically the south-central region of the country. Approximately $30 \%$ of production however is for the export market, accounting for almost half the total Brazilian fruit exports of (BRASIL, 2010).

For fresh consumption, one of the most important crops is the mango, being produced in all states of the Northeast, particularly in irrigated areas, where high fruit yields and quality are achieved. This crop involves a large annual turnover in the domestic and foreign markets, guaranteeing its economic and social importance (XAVIER et al., 2009).

The acerola is not normally a very attractive fruit for fresh consumption, as it generally presents an acid and astringent taste, is very perishable and deteriorates rapidly. However, the consumption of fresh acerola fruit may be stimulated through the availability of firmer, sweeter and less acidic varieties. It is recognized, however, that these characteristics are strongly influenced by climatic conditions and management of the orchards (RITZINGER; RITZINGER, 2011).

The guava is an excellent fruit for human consumption, given its high content of vitamin $\mathrm{C}$, carotenoids, phenolic compounds and minerals, in addition to having low calorie content and good antioxidant potential (DURIGAN; MATTIUZ; MORGADO, 2009). It is widely cultivated in irrigated, semi-arid areas (FREITAS; ALVES, 2008). However, market expansion is subject to the regular supply of best-quality fruits with a greater postharvest life.

On a smaller scale of cultivation compared to the other fruits, production of the custard apple and atemoya has space in the market due to their specific characteristics. Compared to the custard apple, fruit of the atemoya has the advantage of a sweet, slightly acidic flavour and aroma, fewer seeds and greater postharvest life (MOSCA; LIMA, 2003). Its introduction into the northeast is recent, with the Gefner cultivar predominating, being initially grown in the irrigation projects of the Lower Basin of the São Francisco Valley.

Regardless of the area of production, agricultural activity can only be strengthened through investment in technology that ensures the quality of the fruit and results in marketing differences and access to different consumer profiles. In this context, the present study aimed to evaluate the physical, chemical and physico-chemical characteristics of fruits of commercial cultivars of mango, acerola, guava, custard apple and atemoya, produced in the Lower Basin of the São Francisco Valley.

\section{MATERIAL AND METHODS}

The fruit harvested for the study were collected from orchards under commercial production in the Lower Basin of the São Francisco Valley, in the towns of Petrolina PE and Juazeiro BA $\left(09^{\circ} 09^{\prime \prime} \mathrm{S}, 40^{\circ} 22^{\prime}\right.$ 'W, at an average altitude of $365.5 \mathrm{~m}$ ). According to the Köppen classification, the climate in the region is of type Bswh, corresponding to very hot semi-arid. The annual rainfall is $571.5 \mathrm{~mm}$ with an average annual temperature of $26.4{ }^{\circ} \mathrm{C}$, with an average minimum of $20.6^{\circ} \mathrm{C}$ and average maximum of $31.7{ }^{\circ} \mathrm{C}$ (EMPRESA BRASILEIRA DE PESQUISA AGROPECUÁRIA, 2013).

Fruits were evaluated from cultivars of the mango (Van Dyke, Tommy Atkins, Haden, Kent, Palmer, Keitt, Espada and Rosa), acerola (Sertaneja, Okinawa, Costa Rica and Flor Branca), guava (Paluma, Rico and Pedro Sato), atemoya (Gefner) and custard apple.

Harvesting was carried out by hand in the early hours of the day, from March to October of 2009 depending on the fruit crop being studied.

The fruits of the mango, guava, custard apple and atemoyas were harvested at physiological maturity (maturation stage 'ready'). Once harvested, they were placed into cardboard boxes and transported to the Laboratory of Post-Harvest Physiology of Embrapa Semiárido in Petrolina PE, where they remained at room temperature $\left(25.9 \pm 1.7^{\circ} \mathrm{C}\right.$ and $\left.66 \pm 5 \% \mathrm{RH}\right)$ until reaching the maturation stage required in this study (mature). For fruit of the acerola, the commercial maturation stage was adopted, characterised by a red colouration, typical of the ripe fruit, but still firm enough to withstand handling.

When the fruits of the mango, guava, custard apple and atemoya were ripe, they were divided into four replications, each made up of 20 fruits from each cultivar. For the acerola, four replications of 25 fruits were used for conducting physical tests, while for the physico- 
chemical and chemical analyses, the same number of replications was used, each with a sample of $2 \mathrm{~kg}$.

The variables analysed were: a) weight $(\mathrm{g})$, determined with a semi-analytic balance, accurate to $0.1 \mathrm{~g}$; b) length and diameter $(\mathrm{cm})$, obtained with digital calipers; c) colouration of the skin and pulp, evaluated by reflectometer, using luminance $(\mathrm{L})$, chroma $(\mathrm{C})$ and hue $(\mathrm{H})$; d) firmness of the pulp $(\mathrm{N})$, measured by a manual penetrometer with an $8 \mathrm{~mm}$ diameter tip for the mango, guava and atemoya, and by a digital electronic texturometer with a $2 \mathrm{~mm}$ tip for the acerola; e) resistance of the custard apple pulp to compression $(\mathrm{N})$, using a digital electronic texturometer with a $\mathrm{P} / 75$ pressure plate and measuring the force required to cause a 20\% compression in fruit volume; f) level of soluble solids ( ${ }^{\circ}$ Brix), obtained with an $\mathrm{ABBE}$ digital refractometer having a scale of 0 to $65{ }^{\circ} \mathrm{Brix}$, in accordance with the methodology recommended by the Association of Official Analytical Chemistry (1995); g) total soluble sugars, by the anthrone method, according to the methodology described by Yemn and Willis (1954); h) level of reducing sugars, extracted in distilled water and determined as per Miller (1959); i) $\mathrm{pH}$, determined directly from the pulp, using a glass membrane potentiometer in accordance with the recommendation of the Association of Official Analytical Chemistry (1995); j) titratable acidity, determined by titration with a $0.1 \mathrm{~N} \mathrm{NaOH}$ solution, expressing the results as a percentage of malic acid for the acerola, and of citric acid for the other fruits; k) levels of SS to TA, obtained by the ratio between these two variables; 1) starch content, determined according to a methodology described by Association of Official Analytical Chemistry (1995); and $\mathrm{m}$ ) levels of pectic substances, extracted following a procedure described by McCready and McComb (1952). The physical variables were measured in all the fruits individually, and the physico-chemical and chemical variables by experimental plot, homogenizing the fruit that made up each sample prior to analysis.

The results underwent descriptive statistical analysis to get the mean and standard deviation for each characteristic in the fruit cultivar being analysed.

\section{RESULTS AND DISCUSSION}

As shown in Table 1, the fruits of the mango cultivars Tommy Atkins, Haden and Rosa presented weights which meet the standards required for export to the European market, that is from 300 to $450 \mathrm{~g}$, while the first two, as well as Van Dyke, Kent, Palmer, Keitt and Rosa, satisfied the requirements of 250 to $600 \mathrm{~g}$ in force in the United States

Table 1 - Physical characteristics of fruits from different cultivars, produced in the Lower Basin of the São Francisco Valley (mean \pm $\mathrm{SD}, \mathrm{n}=80$ for mango, guava, custard apple and atemoya, $\mathrm{n}=100$ for acerola)

\begin{tabular}{cccccc}
\hline Fruit & Cultivar & Weight $(\mathrm{g})$ & Length $(\mathrm{cm})$ & Diameter $(\mathrm{cm})$ & Pulp firmness $(\mathrm{N})$ \\
\hline \multirow{6}{*}{ Mango } & Van Dyke & $280.24 \pm 14.57$ & $9.67 \pm 0.14$ & $6.84 \pm 0.09$ & $7.70 \pm 0.41$ \\
& Tommy Atkins & $533.68 \pm 19.61$ & $11.80 \pm 0.16$ & $8.98 \pm 0.16$ & $9.45 \pm 0.46$ \\
& Haden & $434.07 \pm 20.93$ & $10.35 \pm 0.13$ & $8.34 \pm 0.09$ & $7.87 \pm 1.25$ \\
& Kent & $565.52 \pm 37.88$ & $11.62 \pm 0.42$ & $8.98 \pm 0.86$ & $6.71 \pm 2.49$ \\
& Palmer & $515.83 \pm 29.46$ & $13.05 \pm 0.27$ & $8.14 \pm 0.18$ & $8.22 \pm 1.18$ \\
& Keitt & $505.08 \pm 24.56$ & $12.80 \pm 0.26$ & $7.74 \pm 0.11$ & $5.06 \pm 0.38$ \\
& Espada & $214.98 \pm 5.54$ & $10.66 \pm 0.28$ & $5.82 \pm 0.07$ & $7.56 \pm 0.61$ \\
Acerola & Rosa & $327.39 \pm 7.22$ & $9.67 \pm 0.31$ & $7.07 \pm 0.03$ & $16.92 \pm 0.77$ \\
& Sertaneja & $6.07 \pm 0.31$ & $1.89 \pm 0.08$ & $2.28 \pm 0.09$ & $2.19 \pm 0.04$ \\
& Okinawa & $9.88 \pm 0.58$ & $2.35 \pm 0.08$ & $2.70 \pm 0.06$ & $2.62 \pm 0.32$ \\
& Costa Rica & $7.64 \pm 0.23$ & $2.08 \pm 0.04$ & $2.41 \pm 0.05$ & $2.38 \pm 0.07$ \\
Guava & Flor Branca & $4.09 \pm 0.29$ & $1.69 \pm 0.02$ & $1.96 \pm 0.04$ & $2.14 \pm 0.15$ \\
\hline Custard Apple & Paluma & $260.74 \pm 24.04$ & $9.46 \pm 0.54$ & $7.46 \pm 0.24$ & $18.79 \pm 0.86$ \\
\hline Atemoya & Rica & $203.23 \pm 32.22$ & $8.51 \pm 0.60$ & $6.88 \pm 0.36$ & $12.23 \pm 1.25$ \\
\hline
\end{tabular}

*No cultivars of the custard apple are available 
(CORREIA; ARAÚJO, 2010). For dimension, the Palmer and Keitt cultivars showed the greatest lengths: 13.05 and $12.80 \mathrm{~cm}$ respectively. The largest diameters were seen in fruits from the cultivars Tommy Atkins $(8.98 \mathrm{~cm})$, Haden $(8.34 \mathrm{~cm})$, Kent $(8.98 \mathrm{~cm})$ and Palmer $(8.14 \mathrm{~cm})$, with these characteristics being peculiar to each cultivar.

Fruit of the Acerola cultivars Sertaneja, Okinawa, Costa Rica and Flor Branca (Table 1) presented a weight greater than $4 \mathrm{~g}$, and length and diameter greater than 1.5 $\mathrm{cm}$, the minimum required by the processing industries (INSTITUTO BRASILEIRO DE FRUTAS, 1995). For these fruits, dimension is a relevant feature, because the larger the fruit, the easier and faster the harvesting, requiring less labour and thus reducing production costs. For this feature, the Okinawa acerola stands out when compared to other the cultivars.

The fruits of the guava cultivar Paluma had the highest average values for weight, length and diameter compared to the others under study (Table 1). The cultivar Pedro Sato showed the smallest difference between length and diameter, having an oblong shape, while the Rica and Paluma cultivars were characterised by a pyriform shape.

Between the two annonaceae studied, the values for the weight and size of the fruit were lower in the custard apple, as shown in Table 1. For the Gefner atemoya, the observed values were similar to those reported by Pereira et al., (2009), who evaluated the quality of bagged fruits during development on the plant. However, it is recognized that variations in the physical characteristics for these and other fruits arise in general from management practices and from determinant environmental conditions during the production cycle.

For firmness of pulp, the greatest values were seen in fruits of the mango cultivar Rosa, and guava cultivars Paluma, Pedro Sato and Rica (Table 1). This characteristic is of great importance in determining the quality of the fruit, as it has a direct effect on resistance to transport, conservation and attack by microorganisms (AWAD, 1993). The average figures found in the guava cultivars were higher than those obtained by Abreu et al. (2012), who reported a firmness of $3.0 \mathrm{~N}$ after the fourth day of storage at room temperature for the cultivar Pedro Sato.

The acerolacultivars Flor Branca, Sertaneja, Costa Rica and Okinawa displayed the lowest firmness among the fruits being analysed, which, given the management conditions and post-harvest technologies practised in the country, should be reflected in a shorter shelf life in relation to the remainder, hampering sale in natura. Araújo et al. (2009), working with the acerola clones Apodi, Cereja, Frutacor, II 47/1, Roxinha and Sertaneja, observed average values of $4.78,4.50,3.80,4.05,4.58$ and $3.97 \mathrm{~N}$ respectively.

Fruit colouration is a quality attribute which is important in marketing, being recognised as a factor for attracting the consumer. It therefore becomes important to characterise colouration for different cultivars and growing conditions, as well as to recognise the physiological factors and processes that modify it. It was found that fruits of the guava cultivars Pedro Sato, Rica and Paluma had the highest average values for luminance (Table 2). In these fruits, the average values for $\mathrm{H}$ in the peel close to 100 represent the yellow colouration of the three cultivars. These values were similar to those found by Abreu et al. (2012) in guava of the cultivar Pedro Sato stored at room temperature.

For mangoes from the cultivars Haden, Kent, Keitt, Espada and Rosa, the average values for $\mathrm{H}$ of the peel ranged from 94.45 to 113.44 , characterising them as of yellowish colouration, while the cultivars Van Dyke, Tommy Atkins and Palmer presented an orange colour (Table 2). This colouration is related to the presence of carotenoids, which are the pigments responsible for most of the yellow and orange colours present in many fruits. High values for carotenoids are desirable because these compounds have antioxidant properties and are known to reduce the risk of development of degenerative diseases, such as cancer, cardiovascular disease, cataracts and macular degeneration (RODRIGUEZ et al., 2006).

The values for $\mathrm{H}$ seen in the peel of the acerola cultivars ranged from 9.17 to 14.04 , corresponding to a purplish-red colouration (Table 2). The red colouration reflects the content and distribution of anthocyanins in the tissue, the amount of chromoplasts that store these pigments, the formation of anthocyanin-metal complexes and the pH (CHITARRA; CHITARRA, 2005).

In the fruits of the annonaceae, where dark senescence spots develop in the peel very quickly, the values for $\mathrm{C}$ seen in this study, which are comparable to those of the guava and some mango cultivars, indicate a better appearance, due to the uniformity of colouration and absence of defects related to depigmentation, and a high potential for consumer acceptance (Table 2). However, in the pulp, values for $\mathrm{C}$ were lower than the general average, indicating a lower colour intensity (Table 3). Moreover, when compared to the other fruits, the custard apple and the atemoya displayed greater brightness of the pulp.

Among the mango cultivars, the fruits of Palmer and Espada stood out for having presented one of the greatest values for luminance and chroma of the pulp, indicating greater intensity and purity of colour, which may be a deciding factor in consumer preference. Liu et al. (2013), evaluating the physico-chemical and antioxidant properties of the four major mango cultivars grown in southern China (Tainong No 1, Irwin, Jin Hwang and Keitt), obtained values for $\mathrm{L}$ and $\mathrm{C}$ in the pulp higher than in the cultivars analysed in this study. The same authors found values for $\mathrm{H}$ in the pulp ranging from 81.97 to 82.29 , characterising an orange colouration. For this characteristic there is a similarity with 
most of the cultivars studied, with the exception of Kent (93.73) and Espada (95.11), which displayed a yellow colouration of the pulp (Table 3).

The acerola cultivars displayed an $\mathrm{H}$ of the pulp ranging from 58.13 to 75.37 , reflecting the orange colouration of the four cultivars (Table 3). For the Paluma, Rica and Pedro Sato guava, the hues of the pulp were close to those obtained by Abreu et al. (2012) who, after eight days of storage of the cultivar Pedro Sato, found values of around 35 for this variable, corresponding to a red colouration.

Among the fruits under evaluation, the acerola cultivars Okinawa, Sertaneja, Flor Branca and Costa Rica were the ones with the greatest titratable acidity, and consequently the lowest average $\mathrm{pH}$ values (Table 4). Oliveira et al. (2012), who evaluated the fruit of five acerola clones at different stages of maturation, reported that the ripe fruit had average values of titratable acidity ranging from 1.24 to $1.81 \%$ malic acid, and a $\mathrm{pH}$ ranging from 3.38 to 350 . These results are within the range seen in the present study.

As shown in Table 4, it was seen that the atemoya and custard apple displayed the highest levels of soluble solids (SS) among the fruits under study. Orsi et al. (2012) characterised the custard apple and atemoya as having average levels for SS of 22.0 and 25.1 respectively. Soluble solids consist of substances that are dissolved in the fruit pulp, having sugars as the main constituents, and are a decisive factor in the acceptance of fruit, depending on the market.

Although the acerola showed the lowest levels of SS, with an average ranging from 7.3 to $8.7^{\circ} \mathrm{Brix}$, all the cultivars under analysis reached values that are compatible with export requirements (Table 4). These requirements correspond to a minimum level of $7.0^{\circ}$ Brix for Europe and $7.5^{\circ}$ Brix for Japan (RITZINGER; RITZINGER, 2011).

Among the mango cultivars, Palmer had the highest SS to TA ratio, followed by Van Dyke (Table 4). A result that may be explained by the higher levels of SS and lower titratable acidity in these cultivars. The SS to TA ratio indicates the degree of sweetness of the fruit or its product, giving information about the predominant flavour, whether sweet or sour or a balance of the two. According to Chitarra and Chitarra (2005), this ratio is one of the most used methods of evaluating taste, being more representative than the isolated measuring of sugars or acidity. SiSlva et al. (2012), studying the genetic diversity of 15 mango cultivars produced in the Forest Zone of the state of Minas Gerais, reported average values for this ratio of from 10.4 to 86.5 in the fruit, with the Extrema and Tommy Atkins cultivars respectively representing these limits.

Table 2 - Attributes of colour, L (luminance), C (chroma) and H (hue), of the peel of fruits of different cultivars produced in the Lower Basin of the São Francisco Valley (mean \pm SD, n = 80 for mango, guava, custard apple and atemoya, $\mathrm{n}=100$ for acerola)

\begin{tabular}{lcccc}
\hline Fruit & Cultivar & L & C & H \\
\hline \multirow{4}{*}{ Mango } & Van Dyke & $47.72 \pm 0.27$ & $37.90 \pm 0.35$ & $87.83 \pm 0.88$ \\
& Tommy Atkins & $41.74 \pm 1.00$ & $26.53 \pm 1.99$ & $86.65 \pm 1.87$ \\
& Haden & $49.80 \pm 0.89$ & $28.29 \pm 0.68$ & $95.28 \pm 2.72$ \\
& Kent & $39.55 \pm 2.19$ & $17.17 \pm 4.22$ & $112.76 \pm 3.61$ \\
& Palmer & $38.86 \pm 0.56$ & $33.58 \pm 0.75$ & $87.62 \pm 1.44$ \\
& Keitt & $31.55 \pm 0.74$ & $32.16 \pm 1.62$ & $113.36 \pm 1.42$ \\
Acerola & Espada & $40.19 \pm 0.96$ & $31.47 \pm 1.45$ & $113.44 \pm 2.35$ \\
& Rosa & $45.79 \pm 0.33$ & $34.60 \pm 0.30$ & $94.45 \pm 0.43$ \\
\hline Guava & Sertaneja & $21.94 \pm 1.68$ & $19.77 \pm 0.78$ & $14.04 \pm 1.86$ \\
& Okinawa & $23.68 \pm 0.31$ & $22.33 \pm 1.10$ & $12.05 \pm 1.95$ \\
& Costa Rica & $20.48 \pm 0.51$ & $16.36 \pm 0.29$ & $10.12 \pm 0.30$ \\
Custard Apple* & Flor Branca & $21.65 \pm 0.54$ & $16.50 \pm 0.97$ & $9.17 \pm 2.89$ \\
\hline Atemoya & Paluma & $49.97 \pm 0.78$ & $28.82 \pm 1.63$ & $100.52 \pm 4.07$ \\
\hline
\end{tabular}

* No cultivars of the custard apple are available 
Table 3 - Attributes of colour, L (luminance), C (chroma) and H (hue), of the pulp of fruits of different cultivars produced in the Lower Basin of the São Francisco Valley (mean \pm SD, $n=80$ for mango, guava, custard apple and atemoya, $n=100$ for acerola)

\begin{tabular}{|c|c|c|c|c|}
\hline Fruit & Cultivar & $\mathrm{L}$ & $\mathrm{C}$ & $\mathrm{H}$ \\
\hline \multirow{8}{*}{ Mango } & Van Dyke & $33.78 \pm 0.76$ & $29.78 \pm 2.93$ & $82.61 \pm 5.29$ \\
\hline & Tommy Atkins & $40.59 \pm 1.11$ & $28.30 \pm 3.12$ & $84.97 \pm 1.89$ \\
\hline & Haden & $40.44 \pm 2.99$ & $24.95 \pm 4.76$ & $81.70 \pm 2.23$ \\
\hline & Kent & $41.17 \pm 1.83$ & $26.44 \pm 5.33$ & $93.73 \pm 7.77$ \\
\hline & Palmer & $42.95 \pm 1.55$ & $40.11 \pm 2.00$ & $89.06 \pm 2.76$ \\
\hline & Keitt & $38.00 \pm 2.46$ & $33.94 \pm 3.61$ & $88.73 \pm 4.16$ \\
\hline & Espada & $40.95 \pm 0.65$ & $38.11 \pm 2.74$ & $95.11 \pm 2.41$ \\
\hline & Rosa & $33.35 \pm 0.84$ & $35.03 \pm 3.23$ & $83.64 \pm 1.61$ \\
\hline \multirow{4}{*}{ Acerola } & Sertaneja & $34.40 \pm 2.14$ & $21.58 \pm 1.95$ & $58.13 \pm 6.09$ \\
\hline & Okinawa & $36.56 \pm 0.82$ & $18.03 \pm 0.44$ & $75.37 \pm 6.21$ \\
\hline & Costa Rica & $34.25 \pm 1.15$ & $18.47 \pm 0.72$ & $59.79 \pm 4.52$ \\
\hline & Flor Branca & $33.99 \pm 0.73$ & $21.88 \pm 0.80$ & $67.52 \pm 2.87$ \\
\hline \multirow{3}{*}{ Guava } & Paluma & $38.60 \pm 1.82$ & $16.92 \pm 1.42$ & $23.44 \pm 5.46$ \\
\hline & Rica & $35.66 \pm 1.84$ & $23.16 \pm 1.20$ & $27.05 \pm 4.40$ \\
\hline & Pedro Sato & $36.35 \pm 2.66$ & $17.45 \pm 1.95$ & $24.17 \pm 8.63$ \\
\hline Custard Apple* & & $51.48 \pm 1.91$ & $10.86 \pm 1.79$ & n.d. \\
\hline Atemoya & Gefner & $44.19 \pm 0.31$ & $19.79 \pm 0.60$ & n.d. \\
\hline
\end{tabular}

*No cultivars of the custard apple are available; n.d.= not determined

Table 4 - pH, titratable acidity (TA), levels of soluble solids (SS) and SS to TA ratio in fruits of different cultivars produced in the Lower Basin of the São Francisco Valley (mean \pm SD; $n=4$, each plot consisting of 20 fruits for mango, guava, custard apple and atemoya, or of 25 fruits for acerola)

\begin{tabular}{lccccc}
\hline Fruit & Cultivar & $\mathrm{pH}$ & $\mathrm{TA}(\%)$ & $\mathrm{SS}\left({ }^{\circ} \mathrm{Brix}\right)$ & $\mathrm{SS} / \mathrm{TA}$ \\
\hline \multirow{4}{*}{ Mango } & Van Dyke & $4.52 \pm 0.06$ & $0.25 \pm 0.00$ & $18.1 \pm 0.60$ & $71.26 \pm 2.32$ \\
& Tommy Atkins & $4.62 \pm 0.17$ & $0.27 \pm 0.02$ & $13.4 \pm 0.57$ & $49.55 \pm 3.89$ \\
& Haden & $4.33 \pm 0.07$ & $0.40 \pm 0.07$ & $14.3 \pm 0.50$ & $36.12 \pm 6.01$ \\
& Kent & $4.00 \pm 0.23$ & $0.39 \pm 0.08$ & $12.2 \pm 0.84$ & $31.67 \pm 5.41$ \\
& Palmer & $4.62 \pm 0.05$ & $0.15 \pm 0.03$ & $15.3 \pm 0.49$ & $98.54 \pm 18.59$ \\
& Keitt & $4.45 \pm 0.08$ & $0.26 \pm 0.04$ & $12.0 \pm 0.76$ & $46.51 \pm 5.54$ \\
& Espada & $3.88 \pm 0.14$ & $0.55 \pm 0.08$ & $14.5 \pm 0.50$ & $26.29 \pm 3.25$ \\
Acerola & Rosa & $3.90 \pm 0.00$ & $0.59 \pm 0.02$ & $13.8 \pm 0.74$ & $23.44 \pm 1.36$ \\
& Sertaneja & $3.15 \pm 0.06$ & $1.74 \pm 0.02$ & $7.3 \pm 0.05$ & $4.22 \pm 0.04$ \\
& Okinawa & $3.25 \pm 0.06$ & $1.87 \pm 0.06$ & $8.7 \pm 0.15$ & $4.67 \pm 0.13$ \\
& Costa Rica & $3.45 \pm 0.06$ & $1.11 \pm 0.03$ & $8.3 \pm 0.15$ & $7.45 \pm 0.18$ \\
Guava & Flor Branca & $3.30 \pm 0.00$ & $1.35 \pm 0.02$ & $7.6 \pm 0.30$ & $5.65 \pm 0.26$ \\
\hline Custrad Apple* & Paluma & $3.92 \pm 0.07$ & $0.59 \pm 0.05$ & $11.1 \pm 0.75$ & $18.87 \pm 2.52$ \\
\hline Atemoya & Rica & $4.11 \pm 0.08$ & $0.45 \pm 0.03$ & $10.1 \pm 0.46$ & $22.47 \pm 1.96$ \\
\hline
\end{tabular}

*No cultivars of the custard apple are available 
It was further seen that among the annonaceae, the custard apple showed a higher SS to TA ratio; a result of having a level of soluble solids equivalent to the atemoya, and a titratable acidity $54 \%$ lower than that fruit. These results confirm the observations of Mosca and Lima (2003), who state that the atemoya has a sweet taste which is slightly acidic and aromatic, representing an advantage with respect to the custard apple.

For total soluble sugars, the fruit of the atemoya and the custard apple had the highest levels, 22.03 and $19.85 \mathrm{~g} 100 \mathrm{~g}^{-1}$ respectively (Table 5). These results support those observed by Orsi et al. (2012) of

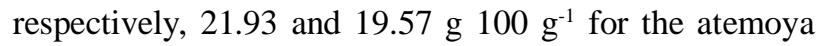
and custard apple.

The levels of total soluble sugars observed in the

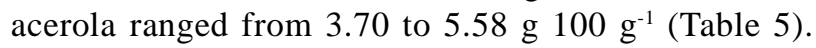
It was found that among the acerola fruit, the cultivar Costa Rica had the highest levels of total soluble sugars. It can therefore be assumed that this cultivar represents a greater possibility for the development of industrial products with a lower use of sugar.

The highest levels of reducing sugars were

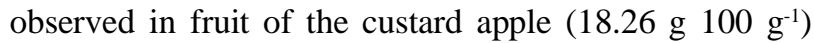

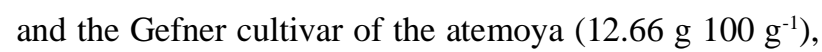
as shown in Table 5. These values indicate that this type of sugar made up $91.98 \%$ and $57.46 \%$ of the total soluble sugars present in these fruits respectively.

Among the fruits being evaluated, the custard apple also had the highest starch content (Table 5), this being one of the elements which contribute to firmness (CHITARRA; CHITARRA, 2005). Lima, Alves and Figueiras (2010) observed in freshly harvested fruits of another annonacea, the

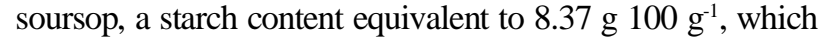
due to intense degrading activity was reduced to only $31 \%$ of the initial value after eight days of storage. The decrease was even greater when the storage time was extended.

The lowest starch contents were observed in the mango cultivars Van Dyke, Tommy Atkins, Haden, Kent, Palmer, Keitt and Rosa, as well as in the fruits of the acerola cultivars Sertaneja, Costa Rica and Flor Branca (Table 5). Results observed for the mango were lower than those discussed by Silva et al. (2012), who when studying 15 cultivars, found

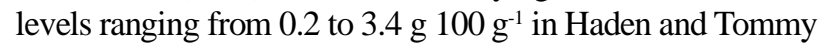
Atkins respectively. In the present study, the greatest starch content in ripe mangoes was seen in fruits of the Espada cultivar, equivalent to $0.4 \mathrm{~g} 100 \mathrm{~g}$-1 (Table 5).

Table 5 - Levels for total soluble sugars (TSS), reducing sugars (RS), starch and pectic substances in fruits of different cultivars produced the Lower Basin of the São Francisco Valley (mean \pm SD; $n=4$, each plot consisting of 20 fruits for mango, guava, custard apple and atemoya, or of 25 fruits for acerola)

\begin{tabular}{|c|c|c|c|c|c|}
\hline Fruit & Cultivar & $\operatorname{TSS}\left(\mathrm{g} .100 \mathrm{~g}^{-1}\right)$ & $\mathrm{RS}\left(\mathrm{g} .100 \mathrm{~g}^{-1}\right)$ & Starch $\left(\right.$ g. $\left.100 \mathrm{~g} \mathrm{~g}^{-1}\right)$ & Pectic substâncias (mg.100 g-1) \\
\hline \multirow{8}{*}{ Mango } & Van Dyke & $15.94 \pm 0.15$ & $3.51 \pm 0.25$ & $0.04 \pm 0.02$ & $298.06 \pm 80.51$ \\
\hline & Tommy Atkins & $11.44 \pm 0.93$ & $2.51 \pm 0.19$ & $0.06 \pm 0.03$ & $308.26 \pm 35.44$ \\
\hline & Haden & $13.53 \pm 0.31$ & $2.66 \pm 0.16$ & $0.10 \pm 0.04$ & $258.98 \pm 21.85$ \\
\hline & Kent & $10.89 \pm 0.24$ & $3.70 \pm 0.38$ & $0.05 \pm 0.02$ & $346.98 \pm 59.94$ \\
\hline & Palmer & $13.17 \pm 0.76$ & $3.53 \pm 0.11$ & $0.03 \pm 0.01$ & $266.20 \pm 20.46$ \\
\hline & Keitt & $10.69 \pm 0.62$ & $3.32 \pm 0.17$ & $0.07 \pm 0.03$ & $283.43 \pm 61.45$ \\
\hline & Espada & $12.00 \pm 0.29$ & $5.42 \pm 0.15$ & $0.40 \pm 0.11$ & $321.36 \pm 59.22$ \\
\hline & Rosa & $11.11 \pm 1.18$ & $4.38 \pm 0.22$ & $0.04 \pm 0.01$ & $183.43 \pm 4.10$ \\
\hline \multirow{4}{*}{ Acerola } & Sertaneja & $3.70 \pm 0.15$ & n.d. & $0.08 \pm 0.01$ & $94.93 \pm 14.08$ \\
\hline & Okinawa & $4.62 \pm 0.07$ & n.d. & $0.23 \pm 0.04$ & $246.71 \pm 27.14$ \\
\hline & Costa Rica & $5.58 \pm 0.31$ & n.d. & $0.06 \pm 0.02$ & $95.57 \pm 31.56$ \\
\hline & Flor Branca & $4.49 \pm 0.34$ & n.d. & $0.05 \pm 0.01$ & $101.00 \pm 7.13$ \\
\hline \multirow{3}{*}{ Guava } & Paluma & $7.41 \pm 0.14$ & $6.16 \pm 0.45$ & $0.42 \pm 0.19$ & $685.44 \pm 29.28$ \\
\hline & Rica & $6.63 \pm 0.10$ & $5.45 \pm 0.47$ & $0.38 \pm 0.08$ & $477.82 \pm 132.4$ \\
\hline & Pedro Sato & $6.99 \pm 0.31$ & $6.48 \pm 0.78$ & $0.46 \pm 0.15$ & $494.37 \pm 57.20$ \\
\hline Custard Apple* & & $19.85 \pm 0.47$ & $18.26 \pm 2.60$ & $1.74 \pm 0.24$ & $615.50 \pm 64.18$ \\
\hline Atemoya & Gefner & $22.03 \pm 0.56$ & $12.66 \pm 0.97$ & $0.52 \pm 0.05$ & $431.54 \pm 89.09$ \\
\hline
\end{tabular}

*No cultivars of the custard apple are available; n.d.= not determined 
Fruits of the guava cultivar Paluma were noteworthy due to having the highest levels of pectic substances, followed by the custard apple (Table 5). According to Antunes, Gonçalves and Trevisan (2006), higher levels of pectic substances are important in post-harvest conservation and fruit processing. For industry, pectins are of direct interest, especially when wanting to prepare jellies and sweet-stuffs in bulk, so that the cost of industrial processing decreases when the fruits are rich in these substances. For these fruits, the need for the addition of commercial pectin is smaller, as is the manufacturing time.

Considering that the appearance (freshness, colour, defects and deterioration), texture (firmness, resistance and tissue integrity), flavour and aroma, nutritional value and food safety, are all part of the set of attributes that define quality, knowledge of these characteristics is of extreme importance in meeting the demands of the consumer. Moreover, this knowledge can enable the commercial highlighting of an important feature of a given cultivar, promoting the product. In this way, value can be added to the fruits produced in any one region, especially when it becomes possible to reach the most demanding markets.

\section{CONCLUSIONS}

1. Fruit from cultivars of the guava (Paluma, Rica and Pedro Sato), the custard apple and atemoya display a high level of pectic substances, a characteristic which is favours industrial use;

2. In the mango, a high level of pectic substances was noted in fruit of the cultivars Kent, Espada, Tommy Atkins and Van Dyke;

3. Fruit of the acerola cultivar Costa Rica have a level of soluble solids and low titratable acidity, favouring consumption in natura.

\section{ACKNOWLEDGEMENTS}

The authors wish to thank the Conselho Nacional de Desenvolvimento Científico e Tecnológico (CNPq), for the grant of a scholarship to the lead author; thanks also go to the Banco do Nordeste do Brasil, for the financial support.

\section{REFERENCES}

ABREU, J. R. et al. Ripening pattern of guava cv. Pedro Sato. Ciência e Tecnologia de Alimentos, v. 32, n. 2, p. 344-350, 2012.

ANTUNES, L. E. C.; GONCALVES, E. D.; TREVISAN, R. Alterações de compostos fenólicos e pectina em pós-colheita de frutos de amora-preta. Revista Brasileira de Agrociência, v. 2 , n. 1 , p. 57-61, 2006.

ANUÁRIO Brasileiro da Fruticultura. Santa Cruz do Sul: Gazeta Santa Cruz, 2013. 136 p. ASSOCIATION OF OFFICIAL ANALYTICAL CHEMISTRY. Official methods of analysis. 16. ed. Arlington: AOAC, 1995. $1141 \mathrm{p}$.

ARAÚJO, P. G. L. et al. Qualidade físico-química e química de frutos de clones de aceroleira recobertos com filme de PVC e conservados por refrigeração. Ciências Agrárias, v. 30, n. 4, p. 867-880, 2009.

AWAD, M. Fisiologia pós-colheita de frutos. São Paulo: Nobel, 1993. 114 p.

BRASIL. Ministério da Integração Nacional. Companhia de Desenvolvimento dos Vales do São Francisco e do Parnaíba. Brasília: CODEVASF, 2010. Disponível em: <http://www. codevasf.gov.br>. Acesso em: 10 abr. 2013.

ChITARrA, M. I. F.; CHITARRA, A. B. Pós-colheita de frutas e hortaliças: fisiologia e manuseio. 2. ed. Lavras: UFLA, 2005. $785 \mathrm{p}$.

CORREIA, R. C.; ARAÚJO, J. L. P. Cultivo da mangueira: mercado. Embrapa Semiárido, versão eletrônica. 2010. Disponível em: <http://sistemasdeproducao.cnptia.embrapa. br /FontesHTML/Manga/CultivodaMangueira_2ed/mercado. htm >. Acesso em: 20 jan. 2013.

DURIGAN, J. F.; MATTIUZ, B. H.; MORGADO, C. M. A. Póscolheita e processamento mínimo de goiabas. In: NATALE, W.; ROZANE, D.E.; SOUZA, H. A. de; AMORIM, A. A. (Org.). Cultura da goiaba: do plantio à comercialização. Jaboticabal: FUNEP, 2009. v. 2, p. 429-470.

EMPRESA BRASILEIRA DE PESQUISA AGROPECUÁRIA. Dados meteorológicos da estação agrometeorológica de Bebedouro. Petrolina: Embrapa Semiárido, 2013. Disponível em: <http://www.cpatsa.embrapa.br:8080/servicos/dadosmet/ ceb-mes.html>. Acesso em: 03 mar. 2013.

FREITAS, B. M.; ALVES, J. E. Efeito do número de visitas florais da abelha melífera (Apis mellifera L.) na polinização da goiabeira (Psidium guajava L.) cv. Paluma. Revista Ciência Agronômica, v. 39, n. 1, p. 148-154, 2008.

INSTITUTO BRASILEIRO DA FRUTICULTURA. Comparativo das exportações brasileiras de frutas frescas 2011/2010. Disponível em: 〈http://www.brazilianfruit.org.br> Acesso em: 03 mar. 2013.

INSTITUTO BRASILEIRO DE FRUTAS. Soluções fruta a fruta: Acerola. São Paulo, 1995. 59 p.

LIMA, M. A. C.; ALVES, R. E.; FILGUEIRAS, H. A. C. Comportamento respiratório e amaciamento de graviola (Annona muricata L.) após tratamento pós-colheita com cera e 1-metilciclopropeno. Ciência e Agrotecnologia, v. 34, n. 1, p. $155-162,2010$.

LIU, F. X. et al. Physico-chemical and antioxidant properties of four mango (Mangifera indica L.) cultivars in China. Journal of Agricultural and Food Chemistry, v. 138, v. 1, p. 396-405, 2013. 
McCREADY, R. M.; McCOMB, E. A. Extraction and determination of total pectic material in fruits. Analytical Chemistry, v. 24, n. 12, p. 1586-1588, 1952.

MILLER, G. L. Use of dinitrosalicylit acid reagent for determination of reducing sugars. Analytical Chemistry, v. 31, n. 3, p. 426-428, 1959.

MOSCA, J. L.; LIMA, G. P. P. Atividade respiratória de atemóia (Annona cherimola Mill. x Annona squamosa L.) cv. Gefner, durante o amadurecimento. In: INTERAMERICAN SOCIETY FOR TROPICAL HORTICULTURE, 2003., Fortaleza. Proceedings... Fortaleza: ISTH, 2003. p. 109-110.

OLIVEIRA, L. S. et al. Antioxidant metabolism during fruit development of different acerola (Malpighia emarginata D.C) clones. Journal of Agricultural and Food Chemistry, v. 60, n. 32, p. 7957-7964, 2012.

ORSI, D. C. et al. Use of sugar apple, atemoya and soursop for technological development of jams - chemical and sensorial composition. Ciência e Agrotecnologia, v. 36, n. 5, p. 560566, 2012.
PEREIRA, M. C. T. et al. Efeito do ensacamento na qualidade dos frutos e na incidência da broca-dos-frutos da atemoieira e da pinheira. Bragantia, v. 68, n. 2, p. 389-396, 2009.

RITZINGER, R.; RITZINGER, C. H. S. P. Cultivo tropical de fruteiras: acerola. Informe Agropecuário, Belo Horizonte, v. 32 , n. 264 , p. $17 \cdot 25,2011$.

RODRIGUEZ, E. B. et al. Phytochemicals and functional foods. Current situation and prospect for developing countries. Segurança Alimentar e Nutricional, v. 13, n. 01, p. 1-22, 2006.

SILVA, D. F. P. et al. Diversidade genética entre cultivares de mangueiras, baseada em caracteres de qualidade dos frutos. Revista Ceres, v. 59, n. 2, p. 225-232, 2012.

XAVIER, I. F. et al. Qualidade pós-colheita da manga 'Tommy atkins' comercializada em diferentes estabelecimentos comerciais no município de Mossoró-RN. Revista Caatinga, v. 22 , n. 4 , p. 7-13. 2009.

YEMN, E. W.; WILLIS, A. J. The estimation of carbohydrate in plant extracts by anthrone. The Biochemical Journal, v. 57, n. 3, p. 508-514, 1954. 